\title{
Nebulised ipratropium bromide and sodium cromoglycate in the first two years of life
}

\author{
R L HENRY, E J HILlER, A D MILNER, I G C HODGES, AND G M STOKES \\ Department of Child Health, University and City Hospitals, Nottingham
}

SUMMARY In a double blind crossover trial, we compared sodium cromoglycate, ipratropium bromide, and water in 23 asthmatic children less than 2 years old (mean age 11.8 months). Each child received nebulised solutions containing $20 \mathrm{mg}$ of sodium cromoglycate, $250 \mu \mathrm{g}$ of ipratropium bromide, or $2 \mathrm{ml}$ water three times a day for three two month periods. Daily symptom scores did not show significant differences between the treatments but parental preferences indicated that both sodium cromoglycate and ipratropium bromide were superior to placebo. Sodium cromoglycate was prophylactic and was more likely to help the older patients. Ipratropium bromide produced an immediate clinical benefit and the response was not age dependent. We were unable to pick responders from non-responders on the basis of lung function tests performed on a routine outpatient basis. Both ipratropium bromide and sodium cromoglycate help some but not all asthmatic children aged less than 2 years.

Asthma is common but difficult to treat in the first two years of life. Salbutamol is ineffective in most children until they are at least 1 year old. ${ }^{1}$ Previous work with the anticholinergic agent, ipratropium bromide, is more encouraging and indicates that about $40 \%$ of young asthmatic children have a significant response, as measured by a fall in airways resistance (Raw) of at least $15 \% .{ }^{2}$ The clinical role of ipratropium bromide has not, however, been established in this age group and the exact role of sodium cromoglycate is also unclear. ${ }^{3}$ Recent studies have included young children with asthma ${ }^{4}{ }^{5}$ but they have not reported whether there is a minimum age at which children respond to sodium cromoglycate.

Anecdotal evidence indicates that only some young asthmatic children respond to ipratropium bromide or sodium cromoglycate. The administration of these drugs to children in the first few years of life requires a compressor and nebuliser, and since these are expensive and not readily available it is very important to find factors that enable us to pick responders from non-responders. This prompted a double blind study comparing nebulised solutions containing placebo, sodium cromoglycate, and ipratropium bromide.

\section{Patients and methods}

Altogether 23 children, 19 boys and four girls, completed the study. Their average age on admission was 11.8 months (range 4.0-23.6 months). All had suffered from recurrent attacks of wheezing and were considered to have troublesome asthma by both their paediatrician and their parents. Twelve had a history of eczema and 14 had a first degree relative with asthma. Blood and skin tests of allergic status were not performed routinely. Ten of the children had previously been admitted to hospital with bronchiolitis. Apart from this we found no conditions such as neonatal ventilation or bronchopulmonary dysplasia that might influence their likelihood of wheezing.

During a two week 'run in' period each child received a nebulised solution containing $2 \mathrm{ml}$ water three times a day via a Sandoz nebuliser and Nebupump compressor. The parents kept a diary card at home, recording cough and wheeze each day and night, as well as concomitant drug treatment. Each symptom was scored from 0 (no symptoms) to 3 (severe) so that the worst possible daily score was 12 .

At the completion of the initial two week evaluation, we assessed lung function and response to water and ipratropium bromide. We sedated the children with $80-100 \mathrm{mg} / \mathrm{kg}$ chloral hydrate and measured thoracic gas volume (TGV), airways resistance (Raw), and specific conductance (sGaw) using total body plethysmography. ${ }^{6-8}$ After initial baseline values were recorded, each child inhaled a 
nebulised solution containing $2 \mathrm{ml}$ of water and the lung function assessment was repeated 15 minutes later. We then administered a $2 \mathrm{ml}$ solution of 250 $\mu \mathrm{g}$ of ipratropium bromide. Final measurements were obtained a further 15 minutes later.

The principal part of the study was a double blind crossover trial comparing $2 \mathrm{ml}$ nebulised solutions containing $20 \mathrm{mg}$ sodium cromoglycate or $250 \mu \mathrm{g}$ of ipratropium bromide with water. These were given three times a day, each for two months. The average ages of the children at the start of the three treatment periods were $14.4,14.4$, and 14.6 months respectively. Symptoms were recorded on diary cards, as in the two week run in period. The 23 children completed the study but three parents lost diary cards for one of the periods, so that we have complete symptom scores for only 20 children.

Fully informed parental consent was obtained for each child and the local ethical committee approved the project. Statistical analysis of lung function data was by paired $t$ tests while other data were analysed by paired Wilcoxon and binomial tests. Diary cards were analysed using the last 50 days of each treatment period and the last 10 days of the run in period.

\section{Results}

The symptom scores for the 20 children with complete diary card records are shown in Table 1. The strong trends for fewer symptoms with sodium cromoglycate failed to reach statistical significance. One of the three children with incomplete records had a symptom score of 101 during the placebo period, compared with 0 on ipratropium bromide. The other two children had missing diary cards for the placebo period, which their mothers reported was very troublesome. Both these children had severe symptoms throughout the trial but their scores on ipratropium bromide (218 and 343) were less than on sodium cromoglycate (316 and 376 respectively). The usage of additional bronchodilators by the whole group was low. Approximately half the children received salbutamol at some stage during the study, in all cases during acute attacks of asthma.

All 23 children completed the trial and the indication of parental treatment preference and parental assessment of whether there was an immediate response to treatment is given (Table 2). As judged by parental preference, both sodium cromoglycate and ipratropium bromide were superior to placebo $(\mathrm{P}<0.05)$ and ipratropium bromide had an immediate clinical benefit for some children $(\mathrm{P}<0 \cdot 05)$.

Lung function results are shown in Table 3 . These
Table 1 Diary card information for the last 50 days of each treatment period in the 20 children with completed records

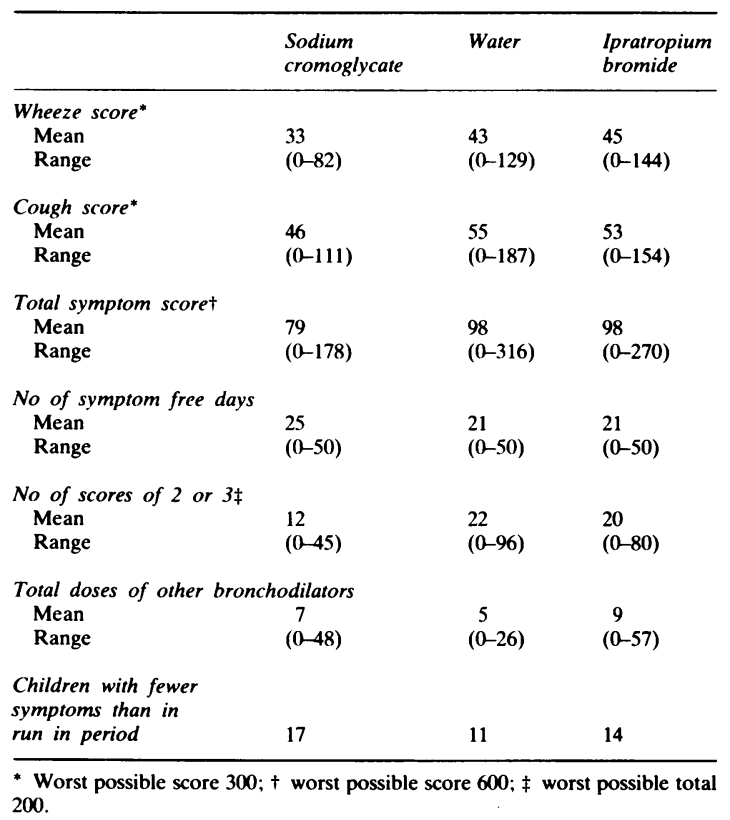

Table 2 Parental assessments of preferred treatment and immediate response to treatment

\begin{tabular}{llll}
\hline & $\begin{array}{l}\text { Sodium } \\
\text { cromoglycate }\end{array}$ & Water & $\begin{array}{l}\text { Ipratropium } \\
\text { bromide }\end{array}$ \\
\hline $\begin{array}{c}\text { Parent preferred } \\
\text { treatment }\end{array}$ & 8 & 1 & 8 \\
$\begin{array}{c}\text { Immediate } \\
\text { beneficial effect }\end{array}$ & 1 & 0 & 6 \\
\hline
\end{tabular}

Table 3 Lung function data at start of trial, including reponses to $2 \mathrm{ml}$ of nebulised water and $250 \mu \mathrm{g}$ of ipratropium bromide $(\mathrm{n}=17)$

\begin{tabular}{llll}
\hline & $\begin{array}{l}\text { Initial } \\
\text { Mean (SD) }\end{array}$ & $\begin{array}{l}\text { After water } \\
\text { Mean (SD) }\end{array}$ & $\begin{array}{l}\text { After } \\
\text { ipratropium } \\
\text { bromide } \\
\text { Mean (SD) }\end{array}$ \\
\hline $\begin{array}{c}\text { TGV (percentage } \\
\text { predicted for } \\
\text { weight) }\end{array}$ & $114(26)$ & $113(24)$ & $111(21)$ \\
$\begin{array}{l}\text { Raw } \\
\left(\mathrm{kPa} 1^{-1} \mathrm{~s}\right)\end{array}$ & $2.08(1.08)$ & $2.22(1.29)$ & $2.02(0.99)$ \\
$\begin{array}{l}\mathrm{SGaw} \\
\left(\mathrm{kPa}^{-1} \mathrm{~s}^{-1}\right)\end{array}$ & $2.0(0.7)$ & $1.9(0.8)$ & $2.1(0.8)$ \\
\hline
\end{tabular}

TGV=thoracic gas volume; Raw=airways resistance; $\mathrm{sGaw}=$ specific conductance. 
were performed on a planned outpatient basis and not during acute attacks of asthma. We found no distinct subgroup who responded dramatically to ipratropium bromide but the presence of possible responders may have been obscured by the fact that many children had normal lung function initially.

The clinical responses of some individual patients convey information that is obscured by the group as a whole. A number of children had notable amelioration in symptoms as soon as they were provided with a nebuliser. In particular, one child had had 8 admissions to hospital in the previous four months but was virtually symptom free for the 6 months of the trial. Other children had wide fluctuations in symptoms during the period of observation and treatment had no obvious benefit. Ipratropium bromide had no prophylactic effect but 6 parents reported an immediate bronchodilator action and felt that this enabled them to manage acute attacks of wheezing effectively.

The benefit of sodium cromoglycate was also notable in a few children. Those who responded to sodium cromoglycate as judged by parental preference had an average age of 16.4 months (range 4.8-25.6 months) compared with an average age of 12.1 months (range 4.4-21.1 months) for those who responded to ipratropium bromide. The tendency for sodium cromoglycate to be more effective in older children seemed to be a factor for predicting who would respond.

\section{Discussion}

Sodium cromoglycate and ipratropium bromide helped some but not all asthmatic children aged less than 2 years. The observations of treatment with ipratropium bromide have important implications. Although regular treatment with ipratropium bromide did not confer any prophylactic benefit, some parents noted a consistent clinical response with decrease in breathlessness, cough, and wheeze for about three hours after treatment. Since the completion of the trial, three of these children have received ipratropium bromide on many occasions with consistent clinical response. This study was not designed to assess the relative merits of salbutamol and ipratropium bromide in childhood asthma but two of the children (both aged less than 1 year) who responded to ipratropium bromide failed on many occasions to respond clinically to nebulised salbutamol. These observations were made by the parents at home and by the medical and nursing staff during inpatient and outpatient attendances. The explanation for these findings is difficult but the observations confirm previous lung function studies performed in the convalescent phase of acute attacks of asthma. ${ }^{1}{ }^{2}$ Clearly only some very young children are helped but our data suggest that a therapeutic trial of ipratropium bromide is indicated in acute asthma in the first year of life.

Sodium cromoglycate is well established in the treatment of asthma in the preschool child and we found strong evidence that it was superior to placebo as judged by both day and night cough and wheeze, symptom free days, troublesome symptoms, parental preference, and improvement compared with the run in period. Although those who responded to sodium cromoglycate were usually older than the group as a whole, one child aged 5 months seemed to be helped.

We have no objective information on drug compliance from this study. Many parents found it very difficult, however, to administer nebulised treatment to young active children. Compliance is probably not a problem during acute episodes of wheezing where the motivation and benefit is immediate but may be a contributing factor to some of the non-responsiveness to sodium cromoglycate.

Most asthmatic children aged under 2 years have neither severe disease nor require the intensive and demanding treatment that a nebuliser and compressor pump involves. Nevertheless, there is a small group for whom most paediatricians regard themselves as therapeutically impotent. We believe that ipratropium bromide during acute attacks and sodium cromoglycate as prophylaxis are two alternatives that do help some but not all of these children.

We thank the parents, Professor D Hull, Drs P Barbor, D Johnston, and $\mathrm{N}$ Rutter who allowed us to study patients under their care. We also thank Fisons and Boehringer Ingelheim for supplying drugs and compressor pumps, and the Asthma Research Council and the Nestle Paediatric Travelling Fellowship (Australia) who provided financial support.

\section{References}

${ }^{1}$ Lenney W, Milner AD. At what age do bronchodilators work? Arch Dis Child 1978;53:532-5.

2 Hodges IGC, Groggins RC, Milner AD, Stokes GM. Bronchodilator effect of inhaled ipratropium bromide in wheezy toddlers. Arch Dis Child 1981;56:729-32.

3 Williams HE, Phelan PD. Administration of disodium cromoglycate to young children. $\mathrm{Br}$ Med J 1973;ii:488.

${ }^{4}$ Geller-Bernstein C, Levin S. Nebulised sodium cromoglycate in the treatment of wheezy bronchitis in infants and young children. Respiration 1982;43:294-8.

5 Miraglia del Giudice M, Capristo A, Maillo N, Apuzzo G. Nebulised sodium cromoglycate for the treatment of asthma in children under five years of age. Modern Problems in Paediatrics 1982;21:122-7.

6 Dubois AB, Botelho SY, Bedell GN, Marshall R, Comroe JH. A rapid plethysmographic method for measuring thoracic gas volume: a comparison with a nitrogen washout method for measuring functional residual capacity in normal subjects. J Clin Invest 1956;35:322-6.

${ }^{7}$ Stocks J, Levy NM, Godfrey S. A new approach for the accurate measurement of airway resistance in infancy. J Appl Physiol 1977;43:155-9. 
${ }^{8}$ Stokes GM, Milner AD, Hodges IGC, Groggins RC. Lung function abnormalities after acute broncholitis. $J$ Pediatr 1981;98:871-4.

${ }^{9}$ Hatch DJ, Taylor BW. Thoracic gas volume in early childhood. Arch Dis Child 1976;51:859-64.
Correspondence to Professor A D Milner, Department of Child Health, E floor, East Block, University Hospital, Queens Medical Centre, Nottingham NG7 $2 \mathrm{UH}$.

Received 3 October 1983

British Paediatric Association

Annual meetings

1984 10-14 April York University

1985 16-20 April York University

1986 15-19 April York University

1987 7-11 April York University 